\title{
Analysis of Environmental and Economic Tradeoffs in Switchgrass Supply Chains
}

\section{for Biofuel Production}

\author{
Jia Zhong ${ }^{\mathrm{i} 1}$, T. Edward Yu ${ }^{\mathrm{i} \dagger}$, James A. Larson ${ }^{\mathrm{i}}$, Burton C. English, \\ Joshua S. Fu ${ }^{\text {ii }}$ and James Calcagno ${ }^{\text {ii }}$
}

${ }^{\mathrm{i}}$ Department of Agricultural and Resource Economics

University of Tennessee

Knoxville, TN 37996-4518

${ }^{\mathrm{ii}}$ Department of Civil and Environmental Engineering

University of Tennessee

Knoxville, TN 37996-2313

${ }^{\dagger}$ T. E. Yu is the corresponding author. Yu’s contact info: 302 Morgan Hall, 2621 Morgan Circle, Knoxville, TN 37996-4518. Tel: +1-865-974-7411. Fax: +1-865-974-9492.

E-mail: tyu1@utk.edu

\footnotetext{
${ }^{1}$ Zhong's present address is 416 Mumford Hall, 1301 Gregory Drive, Urbana, 61801. She is currently a Ph.D. student in the University of Illinois, Urbana Champaign.
} 
Abstract: This study considered the environmental advantages of switchgrass, along with the economic challenges in its logistics, in the design of a sustainable switchgrass supply chain in Tennessee. Applying a multi-objective optimization model to high resolution spatial data, potential tradeoffs among the objectives of minimizing feedstock costs, greenhouse gas (GHG) emissions, and soil erosion were identified for a set of conversion facilities on an efficient frontier. The tradeoff relationship was primarily driven by the type of agricultural land converted to switchgrass. Hay and pasture lands were more cost effective but resulted in higher soil carbon losses and soil erosion after being converted to switchgrass. Converting crop lands reduced GHG emissions and soil erosion but caused higher feedstock cost primarily due to the higher opportunity cost of land use. The respective average costs of abating GHG emissions and soil erosion on the efficient frontier were $\$ 2,378 \mathrm{Mg}^{-1}$ and $\$ 10 \mathrm{Mg}^{-1}$. The compromise-solution conversion-facility site generated $63 \%$ higher feedstock cost compared to the cost minimizing location, while reducing soil erosion by 70 fold and diminishing GHG emissions by $27 \%$. Reducing soil erosion may be a more cost effective environmental criterion than reducing GHG emissions in developing a sustainable switchgrass supply chain in Tennessee.

Keywords: Switchgrass, multi-objective optimization, Supply chains, Greenhouse gas, Soil erosion, Tradeoffs 


\section{$1 \quad 1 \quad$ Introduction $^{1}$}

2 Higher energy prices and the mandate set forth in the Renewable Fuel Standard of the Energy

3 Independence and Security Act of 2007 [1] have driven growth in ethanol produced using corn

4 (Zea mays L.). Changes in land use with expanded corn production have raised concerns about

5 increased soil erosion, fertilizer and pesticide pollution, and greenhouse gas emissions [2]. Corn

6 uses more fertilizer than other major crops and accounted for $46 \%$ of all fertilizer use in the

7 United States in 2010 [3]. Tillage intensity is also higher for corn production than for other crop

8 production, exacerbating water-induced soil erosion [2]. Therefore, the expansion of corn

9 production on existing croplands, set aside agricultural lands, and grasslands [4-7] has

10 aggravated soil erosion [8,9] and losses of nutrients to the environment [10].

11 The US Environmental Protection Agency (EPA) has advocated the production of biofuels

12 from lignocellulosic biomass (LCB) to overcome the aforementioned problems from using grain

13 crops to produce biofuels. In addition, the US EPA's 2014 Clean Power Plan promotes the

14 production of biofuels using LCB as a strategy to reduce GHG emissions [11]. The agency

15 requires that any advanced biofuel generate $60 \%$ fewer lifecycle GHG emissions than gasoline or

16 diesel fuel when measured at 2005 levels [12]. Biofuels produced from LCB, including short-

\footnotetext{
${ }^{1}$ Abbreviations:

LCB - lignocellulosic biomass

GHG - greenhouse gas

USDA - US Department of Agriculture

EPA - Environmental Protection Agency

RUSLE - Revised Universal Soil Loss Equation

MRS - marginal rate of substitution
} 
17 rotation woody crops, agricultural residues, and herbaceous grasses, have great potential for

18 reducing GHG emissions relative to biofuels produced from grain crops (Farrell et al. 2006).

19 Growing perennial grasses to produce biofuels also could reduce soil erosion on agricultural

20 lands [13, 14], an important objective of US agricultural policy [15].

21 Switchgrass (Panicum virgatum), a herbaceous prairie grass native to North America,

22 requires less fertilizer and chemicals, has better water use efficiency, and has greater tolerance to

23 a wide range of environmental conditions when compared to field crops and other herbaceous

24 species $[16,17]$. Because switchgrass is a perennial crop with a life span of 10 or more years, it

25 provides year-round coverage of soils and enhances soils through its extensive root system that

26 reduces water runoff and soil losses and by improving soil organic matter, soil structure, soil

27 water holding capacity, and nutrient holding capacity [18]. Previous studies have suggested that

28 biofuels produced using switchgrass could reduce GHG emissions by $60 \%$ to $90 \%$ when

29 compared with fossil fuels [19] and up to 50\% when compared with biofuels produced using

30 corn grain $[20,21]$.

31 Despite the potential environmental and ecological advantages, the high cost of using

32 switchgrass for biofuels production has impeded development of a switchgrass-based biofuels

33 industry [22, 23]. Biofuels produced using switchgrass costs $17.8 \%$ more than corn and $34.4 \%$

34 more than gasoline when measured on an energy equivalent basis in 2005 dollars [23, 24].

35 Procurement costs in a switchgrass supply chain may constitute $30 \%-50 \%$ of the total cost of 
36 producing biofuels [22, 25, 26]. Important factors contributing to higher supply chain costs

37 include low bulk density of switchgrass; increasing harvest, storage, and transportation costs; and

38 losses of feedstock stored outdoors due to weathering if switchgrass is harvested only once a

39 year [27].

40 Operations research methods have been widely used to evaluate the design of LCB supply

41 chains using cost minimization or profit maximization as the objective of the decision maker

42 (e.g. 25-26, 28). However, an increasing number of studies have examined economic and

43 environmental tradeoffs in the design of a sustainable LCB supply chain [28-32].

44 Notwithstanding the growing literature evaluating tradeoffs in biofuels production, the imputed

45 costs of mitigating environmental degradation or improving environmental quality with biofuels

46 produced using LCB have only been examined on a limited basis [32]. The imputed cost is the

47 proxy value of ecosystem services provided by LCB production such as reduced GHG emissions

48 and soil erosion in the design of a sustainable supply chain [32-33].

49 An assessment of the sustainability of an LCB supply chain depends on the use of high-

50 resolution spatial data to accurately model the characteristics of the supply chain [34]. Spatially

51 oriented factors such as LCB availability, changes in fertilizer and chemical use with LCB

52 production, and feedstock transportation costs and emissions influence the optimal configuration

53 of a sustainable supply chain. Models that use high spatial resolution data generate more detailed

54 predictions of the footprint of the LCB supply chain and are more useful for policy analysis and 
55 for private and public decision making [35]. Most multi-objective studies have not taken into

56 account spatial characteristics, with only a few studies highlighting the value of geographic data

57 in the economic and/or environmental optimization of the LCB supply chain $[29,32,35,36]$.

58 A systematic assessment of the imputed costs of environmental services in a LCB supply

59 chain will contribute to a better understanding by potential stakeholders of the cost-benefit

60 tradeoffs of biofuels production. However, the existing literature lacks an integrated

61 mathematical model valuation that incorporates high-resolution geospatial data on various

62 environmental outputs from LCB supply chains. Acknowledging that gap in the literature, the

63 present study combines the use of detailed spatial data and a multi-criteria optimization model to

64 examine economic and environmental tradeoffs in a LCB supply chain. This study extends the

65 typical tradeoff analysis in bioenergy literature to assess the value of various environmental

66 outputs from LCB supply chains. The fine spatial details included in the LCB supply chains

67 analysis enhances the determination of feedstock draw area and conversion facility location. The

68 detailed data also improves the precision of soil erosion and greenhouse gas emissions estimation

69 from the land use changes required to supply the biomass.

70 The analysis focuses on the optimal location and design of a switchgrass supply chain in

71 Tennessee. The state of Tennessee has several characteristics that lend itself to an evaluation of

72 economic and environmental tradeoffs in biofuels production: a humid subtropical climate that is

73 well suited to the production of high yielding switchgrass, agricultural soils that are highly 
74 erodible, and a geographically diverse set of agricultural production activities and landscapes.

75 Thus, the objectives of this study are: (1) to determine the potential tradeoffs required to

76 minimize feedstock costs, GHG emissions, and soil erosion for a switchgrass supply chain in

77 Tennessee, and (2) to evaluate the imputed costs of abating GHG emissions and soil erosion in

78 the switchgrass supply chain. The valuation of GHG emissions and soil erosion can assist in the

79 development of an economically and ecologically viable advanced biofuel production effort.

\section{Methods and Data}

\section{$82 \quad 2.1$ Supply chain assumptions}

83 Minimization of total switchgrass cost was assumed to be the primary objective of conversion

84 facility decision makers. High feedstock cost has been identified as an important impediment to

85 the development of a switchgrass-based biofuel industry for private investors interested in

86 maximizing profits $[22,23]$. The two environmental criteria, minimization of GHG emissions

87 and minimization of soil erosion are driven by US EPA and US Department of Agriculture

88 (USDA) policies aimed at reducing their levels [12],[15]. The system boundary for calculating

89 switchgrass costs, GHG emissions, and soil erosion produced in the supply chain was from the

90 farm field to the conversion facility plant gate (Figure 1).

92 The switchgrass conversion facility was assumed to produce 189.3 million liters (L) of

93 ethanol year ${ }^{-1}$. The five main feedstock cost components considered in the design of the supply 
94 chain were: (1) land resource allocation, (2) production, (3) harvest, (4) storage, and (5)

95 transportation. Supply chain activities were modeled on a monthly time step. Switchgrass was

96 harvested between November and February after senescence, delivered to the facility or placed in

97 storage during harvest, and delivered from storage to the facility for processing in the off-harvest

98 period from March through October. Assuming a conversion rate of $287.7 \mathrm{~L}$ of ethanol dry $\mathrm{Mg}^{-1}$

99 of switchgrass [37], feedstock required for the facility was 600,892 dry $\mathrm{Mg}_{\mathrm{year}}{ }^{-1}$.

100 The potential switchgrass supply area in this study included all agricultural land in Tennessee

101 and a buffer area of $80 \mathrm{~km}$ contiguous to the state border (Figure 2). Locations for the conversion

102 facility were limited to 150 industrial parks in the Tennessee Valley Authority database [38].

103 Candidate industrial parks had the required space and access to roads and water resources for the

104 facility. The study area was downscaled to a $13 \mathrm{~km}^{2}$ hexagon resolution, defined as the land

105 resource unit, to capture variations in land resources, the transportation network, and other

106 geographic features of the study area. The ratio of crop land to hay and pasture land by land

107 resource unit in Figure 2 indicates that west Tennessee is the major crop production area, while

108 pasture and hay land is primarily located in the eastern region of the state.

109

[Place Figure 2 here]

110 The payoff-table method was used to determine the most preferred solution [39] of the multi-

111 objective feedstock cost, GHG emission, and soil erosion minimization model. The supply chain

112 model considering the aforementioned feedstock cost components was solved for each individual 
113 objective for each of the 150 industrial park sites in the study area. Optima and nadir values and

114 the ranges obtained from solving for each individual objective were used in an improved

115 augmented $\varepsilon$-constraint method [40] to solve the multi-objective function for each potential

116 conversion facility site. Feasible and efficient solutions for all 150 sites in the study area form

117 the efficient-frontier (also called the Pareto-optimal) set of conversion facilities for the study

118 area. The compromise solution method [41] was used to identify the most preferred conversion

119 facility site and the switchgrass draw area for the supply chain on the frontier. Costs of abating

120 GHG emissions and soil erosion in the supply chain were imputed using the frontier solution.

121

$122 \quad 2.2$ Model structure

$123 \quad$ 2.2.1 Cost minimization

124 Following Larson et al. [42], minimization of feedstock cost at the conversion facility plant

125 gate $(T C, \$)$ for the switchgrass supply chain was modeled using Equations (1) to (6):

126 Min $T C=C_{\text {opportunity }}+C_{\text {production }}+C_{\text {harvest }}+C_{\text {storage }}+C_{\text {transportation, }}$

$127 C_{\text {opportunity }}=\left\{\begin{array}{ll}\sum_{i p}\left[\left(\text { Price }_{i p} \times \text { Yield }_{i p}-P C_{i p}\right) \times \mathrm{AH}_{\mathrm{ip}}\right] & , \text { if }\left(\text { Price }_{i p} \times \text { Yield }_{i p}-P C_{i p}-L R_{i p}\right) \geq 0 \\ \sum_{i p}\left(L R_{i p} \times \mathrm{AH}_{\mathrm{ip}}\right) & \text { if }\left(\text { Price }_{i p} \times \text { Yield }_{i p}-P C_{i p}-L R_{i p}\right)<0\end{array}\right.$,

$128 C_{\text {production }}=\sum_{i p}\left((E s t+A M) \times \mathrm{AH}_{i p}\right)$,

129

$C_{\text {harvest }}=\sum_{i p}\left(\sigma_{i} \times \mathrm{AH}_{i p}\right)$,

$130 \quad C_{\text {storage }}=\sum_{m i}\left(\gamma_{i} \times \mathrm{NXE}_{m i}\right)$, and 
$131 C_{\text {transportaion }}=\sum_{i}\left(\theta_{i} \times\left(\sum_{m} \mathrm{XTN}_{m i}+\sum_{m} \mathrm{XTO}_{m i}\right) /\left(1-D M L^{\text {trans }}\right)\right)$.

132 Costs for production $\left(C_{\text {production }}\right)$, harvest $\left(C_{\text {harvest }}\right)$, storage $\left(C_{\text {storage }}\right)$, and transportation

$133\left(C_{\text {transportation }}\right)$ activities in Equation (1) included equipment ownership, maintenance, labor, fuel,

134 and materials used for farm field to plant gate activities in the switchgrass supply chain.

135 Definitions of the cost parameters and decision variables are listed in Table 1. The key

136 parameters in the equations in this section and subsequent sections (2.2.2 and 2.2.3) are

137 summarized in Appendix Table A.

[Placed Table 1 here]

Opportunity cost $\left(C_{\text {opportunity }}\right)$ in Equation 2 was defined as the forgone profit from crop, hay,

140 and pasture production activities from the prior land use or the market rental rate for the land

141 [42]. Cost of switchgrass production $\left(C_{\text {production }}\right)$ in Equation 3 included the annualized

142 establishment cost and annual maintenance cost. Harvest cost $\left(C_{\text {harvest }}\right)$ in Equation 4 assumes

143 switchgrass was processed into large rectangular bales. Storage cost for switchgrass $\left(\gamma_{\mathrm{i}}\right)$ in

144 Equation 5 included materials, equipment, and labor for rectangular bale staging and storage

145 operations. Transportation costs $\left(\theta_{\mathrm{i}}\right)$ in Equation 6 assumed the use of semi-trailer trucks and

146 trailers to transport switchgrass from storage to the conversion facility. Costs for transportation

147 were determined by the time required to perform each activity. Loading and unloading times for

148 bales were taken from a study by Duffy [43]. Distance and truck speed based on highway speed 
149 limits were used to determine transportation time. Maximum travel distance to transport

150 switchgrass to the conversion facility was assumed to be $121 \mathrm{~km}$.

151 The cost minimization was subject to constraints based on practical operation requirements

152 and rules of mass balance:

153 Available area for production: $\sum_{m} \mathrm{AH}_{m i p} \leq A a_{i p}, \forall i, p$ Nov $\leq \mathrm{m} \leq$ Feb.

154 Available harvest working hours: $\mathrm{NM}_{m}^{k} \times$ Avehour $_{m}-\sum_{i}\left(M_{T} B_{i}^{k} \times \mathrm{AH}_{m i p}\right) \geq 0, \forall k, m$.

155 Harvest to shipment and storage balance:

$156 \sum_{p} \mathrm{AH}_{m i p} \times$ Yield $_{i}^{s w g}=\mathrm{XTN}_{m i} /\left(1-D M L^{\text {trans }}\right)+\mathrm{NXE}_{m i}, \quad \forall \mathrm{m}, \mathrm{i}$.

157 Cumulative storage balance during harvest season:

$158 \quad \mathrm{XE}_{(m+1) i}=\left(1-D M L_{m}^{\text {stor }}\right) \times \mathrm{XE}_{m i}+\mathrm{NXE}_{(m+1) i}, \forall \mathrm{m}, \mathrm{i}$ Nov $\leq \mathrm{m} \leq \mathrm{Feb}$.

159 Cumulative storage balance during off-harvest season:

$160 \quad \mathrm{XE}_{(m+1) i}=\left(1-D M L_{m}^{\text {stor }}\right) \times \mathrm{XE}_{m i}-\mathrm{XTO}_{(m+1) i p} /\left(1-D M L^{\text {trans }}\right), \forall \mathrm{m}, \mathrm{i}$ March $\leq \mathrm{m} \leq$ Oct.

161 Ethanol production requirement: $\lambda\left(\sum_{i} \mathrm{XTN}_{m i p}+\sum_{i} \mathrm{X \Gamma O}_{m i}\right)-Q_{m}=0, \forall m$.

162 AH, NXE, XE, XTN, XTO, and NM $\geq 0$.

163 Equation (7) restricts available land area based on switchgrass yields in each land resource

164 unit. Machine hours month ${ }^{-1}$ are constrained in Equation (8) to available harvest days based on

165 weather during harvest. Equation (9) requires switchgrass harvested to equal the summation of

166 switchgrass delivered directly to the conversion facility (XTN) after adjusting for transportation

167 dry matter losses and quantity of feedstock sent to storage (NXE). Equations (10) and (11) 
170 demand for biofuel production in Equation (12). All parameters and variables in the model are

171 nonnegative as required in Equation (13).

\section{$173 \quad$ 2.2.2 GHG emissions minimization}

174 The framework presented by Yu et al. [32] was used to calculate GHG emissions generated

175 in the switchgrass supply chain. Equations (14) through (18) model the minimization of total

176 GHG emissions (TE, $\mathrm{kg} \mathrm{yr}^{-1}$ ) from supply chain activities:

177 Min $T E=E_{\text {luc }}+E_{\text {energy }}+E_{\text {transportation }}+E_{\text {ind }}$.

$178 E_{\text {luc }}=\sum_{p}\left(\sum_{m i} \mathrm{AH}_{m i p} \times\left(\Delta L U C O_{2, P}+\Delta L U C H_{4, P}+\Delta L U N_{2} O_{, P}\right)\right)$,

$E_{\text {energy }}=\sum_{\text {mip }} \mathrm{AH}_{\text {mip }} \times($ ProE + HarE $)+\sum_{\text {mip }} \mathrm{AH}_{\text {mip }} \times$ Yield $_{i}^{\text {swg }} \times$ StorE,

$E_{\text {transportaion }}=\sum_{m i} \operatorname{Trans}_{\text {mip }} \times\left(\mathrm{XTN}_{m i}+\mathrm{XTO}_{m i}\right) /\left(\right.$ Loadwt $\left.\times\left(1-D M L^{\text {trans }}\right)\right)$, and

$E_{\text {ind }}=\sum_{\text {mip }}($ FertE + ChemE + SeedE $) \times \mathrm{AH}_{\text {mip }}+\sum_{m b} \mathrm{NM}_{m b}^{k} \times m a c h E^{k}$.

183 changes in emissions were from adjustments in land use $\left(E_{l u c}\right)$, energy consumption from

184 switchgrass production, storage, and harvest $\left(E_{\text {energy }}\right)$, transportation $\left(E_{\text {transportation }}\right)$, and from the

185 energy used to manufacture seed, fertilizer, chemicals, and machinery $\left(E_{\text {ind }}\right)$ used in the supply

186 chain. Emissions caused by changes in land use were calculated by multiplying the emission 
187 factors for $\mathrm{CO}_{2}, \mathrm{CH}_{4}$, and $\mathrm{N}_{2} \mathrm{O}$ by the area of crop, hay, and pasture lands converted to

188 switchgrass production [Equation (15)]. Energy consumption for switchgrass production and

189 storage activities were calculated through the summation of land area times the farm operations'

190 emission factors and storage weight times the storage emission factor [Equation (16)].

191 Transportation emissions were calculated through the multiplication of the emission factor per

192 truck per route times the truck loads for all transported biomass [Equation (17)]. Indirect

193 emissions are from the manufacture of fertilizer, chemicals, seed, and machinery used in the

194 production of switchgrass [Equation (18)].

195

$196 \quad$ 2.2.3 Soil erosion minimization

197 For the soil erosion minimization objective, changes in water-induced soil erosion from

198 converting crop, hay, and pasture lands to switchgrass production were estimated using the

199 Revised Universal Soil Loss Equation (RUSLE) [44-46]. Water-induced soil erosion is

200 influenced by land use activity (crop, hay, and pasture production), tillage method, landscape,

201 and precipitation factors in the RULSE model. Equation (19) models the annual soil loss (TSoilE,

$202 \mathrm{Mg} \mathrm{ha}^{-1} \mathrm{yr}^{-1}$ ) minimization objective:

203 Min TSoilE $=\sum_{i}\left\{\left(R_{i} \times K_{i} \times L S_{i} \times P_{i}\right) \times \sum_{p}\left[(\Delta C f) \times \sum_{b} \mathrm{AH}_{i p b}\right]\right\}$,

204 where $R$ was rainfall and runoff factor, $K$ was soil erodibility factor, $L S$ was length and steepness

205 of slope factor, $P$ was support practice factor, and $\Delta C f$ was crop vegetation and management 
207 intersect geoprocessing method and pivot table in Excel to estimate weighted average values for 208 each factor for each land resource unit.

209 To evaluate the impact on soil erosion of land conversion to switchgrass, the estimates of

210 TSoilE before and after the conversion of land to switchgrass production were compared with

211 USDA NRCS estimates of soil loss tolerance $\left(T, \mathrm{Mg} \mathrm{ha}^{-1} \mathrm{yr}^{-1}\right)$ by land resource unit [47]. Soil

212 loss tolerance, $T$, is defined in the RULSE2 database as "the maximum amount of soil loss [Mg

$213 \mathrm{ha}^{-1} \mathrm{yr}^{-1}$ ], that can be tolerated and still permit a high level of crop productivity to be sustained

214 economically and indefinitely." [48]. The frequency of land resources where TSoilE $>T$ before

215 and after the conversion of crop, hay, and pasture lands into switchgrass production were

216 evaluated to ascertain the effects of switchgrass production on soil erosion within the switchgrass

217 supply chain area.

\section{$219 \quad 2.3$ Multiple objective optimization}

\section{$220 \quad$ 2.3.1 Improved augmented $\varepsilon$-constraint method in multi-objective program}

221 The improved augmented $\varepsilon^{-}$-constraint method, AUGMECON2 [40], was applied to derive

222 the tradeoff relationship among the three competing objectives for each potential conversion

223 facility location. The tradeoff relationship among objectives indicates that the performance of

224 one objective could not be improved without degrading the performance of the other objectives.

225 The procedure was applied to all 150 potential industrial park locations for conversion facilities 
227 available in Mavrotas and Florios [40].

228 The AUGMECON2 method for the three objectives takes the form:

229 Min. $\left(T C-\varepsilon \times\left(s_{2} / r_{2}+10^{-1} \times s_{3} / r_{3}\right)\right)$,

230 Subject to:

$231 T E+s_{2}=e_{2}$, and

232 TSoilE $+s_{3}=e_{3}$,

233 where $T C, T E$, and TSoilE are the three competing objectives defined in Equations (1), (14), and

234 (19), $\varepsilon$ is a small number (in this study $\varepsilon$ was set to be $10^{-3}$ ), $s$ is the non-negative slack variable,

$235 r_{2}$ and $r_{3}$ are the ranges of the objective functions for TE and TSoilE, $e$ is the constraint applied to

236 the TE and TSoilE through interpolating four grid points to create five equal intervals in the value

237 range $(r)$. The slack variable $s$ was added to the objective function in Equations (20) - (22) to

238 produce only efficient solutions. Minimization of cost was the primary objective with the two

239 environmental criteria as the secondary objectives in the optimization [40].

240 To determine the nadir values and generate the ranges of the TE and TSoilE objective

241 functions, a $3 \times 3$ payoff table was generated by considering each of the objectives as a single

242 objective problem. The diagonal of the payoff table provides the optima values for each of the

243 three objectives. For the TE and TSoilE objectives, the optima were the lower bound values $\left(l_{2}\right)$

244 and $\left(l_{3}\right)$, respectively. The nadir value of $T E$ and $T S o i l E, u_{2}$ and $u_{3}$, respectively, were the 
245 maximum values of TE and TSoilE. The ranges of the objective value for TE and TSoilE were

246 obtained from the differences between upper and lower bound values: $r_{2}=u_{2}-l_{2} ; r_{3}=u_{3}-l_{3}$.

247 The AUGMECON2 method identifies weakly efficient points and bypasses the surplus grid

248 points, reducing computation time [40]. The combination of two sets of grid points for other

249 objectives started from looping through the inner most objective (TE) first from the nadir value

250 grid to the optima value grid, followed by the exterior grid point (TSoilE) after each iteration of

251 the inner objective loop. The feasible solution can be obtained with the first round of relaxed

252 exterior constraints. The rolling computation for the exterior grid point could be saved to reduce

253 computation time if no alternative optima were generated from the prior settings of lexicographic

254 optimization objective in Equation (20). In this study, the algorithm was further improved by

255 eliminating the iteration of the grid points for TSoilE, given that the solutions did not vary from

256 those obtained from iterating the grid points of the $T E$ objective. Thus, the iteration in

257 constrained objectives for a conversion facility site was reduced from $36(6 \times 6)$ to 6 in the

258 solving process, which consequently improved the computation efficiency and reduced

259 computation time by more than $80 \%$.

260

$261 \quad$ 2.3.2 Compromise solution method

262 The set of conversion facilities on the efficient frontier for the study region was developed to

263 evaluate the potential tradeoffs among the three competing objectives. The most preferred 
264 solution point on the frontier was identified using the compromise solution method [41]. The

265 compromise solution optimal point was determined by the minimum distance $(D(S))$, measured

266 by Tchebycheff norms [49], to the ideal point $\left(\mathrm{z}^{*}\right)$ on the frontier:

$267 \mathrm{D}(\mathrm{S})=\max _{j=1, \ldots, 3}\left\{\lambda_{j}\left|z_{j}(S)-z_{j}^{*}\right|\right\}$,

268 where $j$ indexed the objective functions, $\lambda_{\mathrm{j}}$ was the normalized weight for each objective

269 function, and $S$ was the set of points on the frontier. The normalized weight, $\lambda_{\mathrm{j}}$, was defined as:

$270 \quad \lambda_{j}=1 / r_{j} \times\left[\sum_{j=1}^{3}\left(1 / r_{j}\right)\right]^{-1}$,

271 where $r$ was the previously defined objective value range. The ideal point $\left(\mathrm{z}^{*}\right)$ was defined

272 according to the individual minima of each objective $\left(z^{*}=\left[l_{1}, l_{2}, l_{3}\right]\right)$ from the payoff tables. To

273 further illustrate the relative relationship between each point on the frontier and the compromise

274 solution point, a $\mathrm{D}$ score was calculated as the relative value of the $\mathrm{D}(\mathrm{S})$ of each point to the

$275 \mathrm{D}(\mathrm{S})$ of the compromise optimal solution (i.e. the min. $\mathrm{D}(\mathrm{S}))$ :

$276 \quad \mathrm{D}$ score $=[\mathrm{D}(\mathrm{S}) / \min . \mathrm{D}(\mathrm{S})]$.

277 The solution for the efficient frontier was used to impute the costs of mitigating GHG

278 emissions and soil erosion in the supply chain [31]. Two measures of the tradeoffs among higher

279 feedstock costs, lower GHG emissions, and lower soil erosion were calculated using the model

280 solution for the feasible and efficient set of conversion facilities on the efficient frontier. The first

281 approach was to calculate the marginal rate of substitution (MRS) between feedstock cost and

282 GHG emissions. MRS was determined using the ratio of the normalized weights for feedstock 
283 costs and GHG emissions and the ratio of the range of cost to the range of GHG emissions on the

284 efficient frontier [50]. The MRS between feedstock cost and soil erosion was also derived. The

285 respective MRS of cost-GHG emissions and cost-soil erosion provide the average costs $\mathrm{Mg}^{-1}$ of

286 reducing GHG emissions and soil erosion on the frontier. The second approach was to calculate

287 the costs $\mathrm{Mg}^{-1}$ of reducing GHG emissions and soil erosion for the compromise solution

288 conversion facility locations versus the cost minimization solution conversion facility locations.

289 Cost comparisons were also made for the GHG emission and soil erosion minimization

290 conversion facility locations versus the cost minimization solution conversion facility locations.

\section{$292 \quad 2.4$ Data}

293 The data sources and models used in the lexicographic model to estimate feedstock cost,

294 GHG emissions, and soil erosion are summarized in Table 2. The data and derived parameters

295 were all associated with geospatial characteristics of the land resource units. DAYCENT, a daily

296 time-step biogeochemical plant-soil system model, was adopted to simulate soil carbon uptake

297 and $\mathrm{CH}_{4}$ and $\mathrm{N}_{2} \mathrm{O}$ emission factors [51]. The change in soil carbon stock was calculated using

298 IPCC guidelines [52]. Differences in geography and soils between east, middle and west

299 Tennessee were considered in the estimation of soil carbon. Emission factors for energy

300 combustion from farm equipment operations and the indirect emission factors for the

301 manufacturer of agricultural machinery, fertilizer, chemicals, and seed were estimated using the 
302 Greenhouse Gases, Regulated Emissions, and Energy Use in Transportation (GREET) Model

303 [53]. Emissions from feedstock transportation were estimated using the Motor Vehicle Emissions

304 Simulator (MOVES) version 2010b [54], considering travel distance, local weather, travel speed

305 and slopes of roads.

306

[Place Table 2 here]

307

3083 Results and Discussion

$309 \quad 3.1$ Efficient frontier

$310 \quad$ Figure 3 presents the relationships among the three competing objectives for a single

311 conversion facility site (Figure 3-i), all 150 potential sites (Figure 3-ii), and the efficient frontier

312 (Figure 3-iii). The following describes the key components in the frontier that are illustrated in

313 each panel of the chart and the resulting economic implications. First, GHG emissions and soil

314 losses were mitigated in the supply chain when switchgrass procurement costs increased;

315 whereas, GHG emissions and soil erosion were positively correlated with each other (Figure 3-i).

316 The model converted more crop land to accommodate the tradeoffs in lower levels of GHG

317 emissions and soil erosion for higher feedstock costs. Crop lands have higher opportunity costs,

318 larger fertilizer and chemical expenditures, greater soil erosion, and were more geographically

319 dispersed relative to hay and pasture lands. 
321 Second, GHG emissions and soil erosion in the supply chain were less dispersed with low

322 feedstock costs (Figure 3-ii). The ranges of GHG emissions and soil erosion expanded as

323 feedstock costs increased in the model to facilitate tradeoffs in the cost and environmental

324 objectives. Low feedstock costs were associated with the conversion of hay and pasture lands.

325 Abatement of GHG emissions and soil erosion were achieved through the conversion of crop

326 land, leading to a wider dispersion in feedstock costs.

327 Third, a total of 881 feasible solution points were found in the optimization (Figure 3-iii) for

328 the 150 potential conversion facility sites. Black dots on the efficient frontier are the final

329 conversion facility site solution points given that the value of one objective could not be

330 improved without degrading the values of the other two objectives. Among those 881 feasible

331 solution points from 150 sites, there were a total of 40 efficient potential conversion facility sites

332 on the frontier. The individual-optimum solution points for feedstock costs (A), GHG emissions

333 (B), and soil erosion (C) are identified as blue dots on the efficient frontier. The compromise

334 solution point $(\mathrm{O})$ is identified as a red dot.

335 Finally, the tradeoffs between higher feedstock costs and lower GHG emissions or lower soil

336 erosion on the efficient frontier (Figure 3-iii) were imputed using the MRS. For the 40

337 conversion facilities on the frontier, the average cost of abating one $\mathrm{Mg}$ of GHG emissions was

$338 \$ 2,378$. The average abatement cost for GHG emission was considerably higher than the $\$ 10$

339 average cost to reduce soil erosion by one Mg. Results indicated that soil erosion may be a more 
340 cost effective environmental criterion than GHG emissions in the design of a sustainable

341 switchgrass supply chain in Tennessee.

$342 \quad$ Figure 4 further illustrates the tradeoffs among the three competing objectives. D scores for

343 the 40 conversion facilities on the efficient frontier and the geographic locations of the efficient

344 facilities are shown in the figure. The color of each circle is related to the D score and the size of

345 the circle represents the level of feedstock cost (panel i), GHG emissions (panel ii), and soil

346 erosion (panel iii). For example, the compromise solution point $(\mathrm{O})$ had larger feedstock costs

347 and GHG emissions but lower soil erosion relative to many of the other sites on the efficient

348 frontier.

[Place Figure 4 here]

$351 \quad 3.2$ Individual-optima and compromise solution

352 The feedstock draw areas for each individual-optimum conversion facility site and for the

353 compromise solution conversion facility site are displayed in Figure 5. The feedstock draw area

354 for the cost minimization solution (A) was the most geographically compact, while the draw

355 areas for the GHG emission, soil erosion, and compromise solutions (B, C, and $\mathrm{O})$ were more

356 geographically dispersed. Feedstock cost is related to the density of switchgrass production in the

357 conversion facility draw area, which impacts feedstock transportation costs [42]. Crop

358 production is more concentrated in West Tennessee while hay and pasture production is more 
359 prevalent in Middle and East Tennessee. With the two environmental objectives, the model

360 traded off feedstock costs to convert highly erodible crop land to switchgrass in Middle and East

361 Tennessee for the compromise solution $(\mathrm{O})$. Thus, the choice of conversion facility location and

362 feedstock draw area was primarily related to the availability of land resources and existing

363 agricultural production.

364

[Place Figure 5 here]

365 Figure 6 shows the land coverage change for switchgrass production. Hay and pasture lands

366 were primarily selected in the cost minimization solution (A), whereas crop lands were mostly

367 utilized for switchgrass production in the GHG minimization (B) and soil erosion minimization

368 (C) solutions. Converting crop lands to switchgrass resulted in higher opportunity cost from land

369 use selection, increased soil carbon storage, and reduced soil erosion. The opportunity costs for

370 converting hay and pasture lands to switchgrass were lower but resulted in higher soil carbon and

371 soil erosion losses $[19,55]$. Thus, a combination of crop, hay, and pasture lands were utilized in

372 the compromise solution $(\mathrm{O})$ to achieve the integrated multi-objective goal embodied in the

373 compromise solution.

374

[Place Figure 6 here]

375

376 The percentage of land area with soil erosion exceeding USDA NRCS tolerance levels $e x$

377 ante and ex post land converted to switchgrass for the individual-optima and compromise 
378 solutions are shown in Figure 7. Prior to converting land to switchgrass production, nearly $50 \%$

379 of the switchgrass feedstock draw area for the cost minimization solution (A) exceeded tolerance

380 levels. Whereas, all of the land area for the GHG emission (B) and soil erosion (C) minimization

381 solutions had soil erosion exceeding the tolerance level. For the compromise solution (O), almost

382 all $(97 \%)$ of the switchgrass draw area prior to land conversion had soil erosion exceeding the

383 tolerance rate. In contrast, less than $1 \%$ of all land area ex post switchgrass production exceeded

384 the soil erosion tolerance levels for all four solutions. The reduction in soil losses mostly resulted

385 from the year-round ground cover and deep root system provided by perennial switchgrass.

[Place Figure 7 here]

Itemized costs for each of the individual-optima and compromise solutions are summarized

388 in Table 3 . The cost minimization solution (A) had a total plant-gate feedstock cost of $\$ 43.4$

389 million. Harvest cost accounted for $51.6 \%$ of total feedstock cost, followed by production cost at

$39019.8 \%$ of total costs. Opportunity cost of $\$ 1.3$ million for the cost minimization solution was the

391 lowest among the three objectives because low-cost hay and pasture lands were primarily

392 converted to switchgrass production. For the environmental objectives, the two primary factors

393 influencing cost differences were increased opportunity costs, caused by conversion of crop

394 lands that had higher GHG emissions and soil erosion, and increased feedstock transportation

395 costs caused by a more widely dispersed switchgrass production area. Total feedstock cost

396 increased to $\$ 60.5$ million for the GHG minimization solution (B). Opportunity cost for the GHG 
solution was 11.8 times greater and transportation cost was $27.7 \%$ larger than for the cost

398 minimization solution (A). Soil erosion minimization (C) had the highest total cost among all

399 individual optima cases of $\$ 85.4$ million with considerably higher opportunity ( $\$ 35.6$ million)

400 and feedstock transportation ( $\$ 16.1$ million) costs. Total feedstock cost for the compromise

401 solution (O) was $\$ 70.7$ million, $62.9 \%$ higher than the cost minimization solution, but $20.7 \%$

402 lower than the soil erosion minimization solution (C).

The cost effectiveness of switchgrass production in reducing GHG emissions and soil erosion

405 was further evaluated through an examination of differences in cost and abatement amounts

406 among the four solutions (Table 3). The GHG emission minimization (B) solution reduced total

407 net GHG emissions by 59\%, from 44.9 thousand $\mathrm{Mg}$ to 18.6 thousand $\mathrm{Mg}$, but at an increased

408 feedstock cost of $\$ 17$ million when compared to feedstock cost minimization (A) solution (Table

409 3). The imputed cost of abating GHG emissions was $\$ 648 \mathrm{Mg}^{-1}$ ( $\$ 17$ million $/ 26.3$ thousand $\left.\mathrm{Mg}\right)$

410 between the two solutions. Reduction in total emissions resulted from converting crop lands to

411 switchgrass that sequestered more soil carbon and used fewer inputs than the crops it replaced

$412[19,55]$. For the feedstock cost minimization (A) and soil erosion minimization (C) comparisons,

413 the imputed cost of GHG emission sequestration was $\$ 2,765 \mathrm{Mg}^{-1}$ given that feedstock cost

414 nearly doubled and GHG emissions declined by only 33\%. Similarly, the imputed cost of GHG 
415 emissions abatement was $\$ 2,270 \mathrm{Mg}^{-1}$ when comparing the feedstock cost minimization solution 416 (A) to the compromise solution $(\mathrm{O})$.

417 With respect to the soil erosion minimization (C) solution, 7.5 million $\mathrm{Mg}$ of soil erosion was 418 averted at an additional feedstock cost of \$15.2 million when compared with the feedstock cost 419 minimization (A) solution. The imputed cost of reduced soil erosion was $\$ 5.60 \mathrm{Mg}^{-1}$ for the soil 420 erosion minimization (C) solution. Contrasting the GHG emission minimization (B) solution 421 with the cost minimization (A) solution resulted in 3.4 million Mg less soil erosion with an

422 imputed cost of abatement of $\$ 5.00 \mathrm{Mg}^{-1}$. Finally, about 7.4 million $\mathrm{Mg}$ soil erosion was averted 423 with an increase in total feedstock cost of $\$ 12$ million with the compromise solution (O). The 424 imputed cost for conserving soil in the feedstock draw area was the lowest among the four 425 optimal solutions at $\$ 3.70 \mathrm{Mg}^{-1}$. The efficient frontier and compromise solution results indicate 426 that targeting soil erosion as an objective in the development of a sustainable switchgrass supply 427 chain in Tennessee may be more cost effective than targeting GHG emissions.

\section{Conclusions}

430 This study identified an efficient set of switchgrass conversion facilities and draw areas to

431 minimize feedstock costs, GHG emissions, and water-induced soil erosion for a switchgrass

432 supply chain in Tennessee. Results show that the type of agricultural land converted to

433 switchgrass production is crucial in determining feedstock costs and environmental impacts of 
434 the supply chain. For instance, converting only crop lands to switchgrass in the GHG emissions

435 minimization case incurred 10 times higher opportunity cost from land use change but stored 13

436 times more soil carbon and decreased soil erosion by almost 70 folds when compared with the

437 cost minimization case that only converted hay and pasture lands. A mix of crop, hay, and

438 pasture lands (48\% corn, $31 \%$ soybean, $12 \%$ of hay/pasture, $7 \%$ cotton, and $1 \%$ wheat) achieved

439 the goal of integrating the three objectives into the switchgrass supply chain in Tennessee.

440 Given the tradeoffs among minimization of feedstock costs, GHG emissions and soil erosion

441 on the efficient frontier, the imputed cost of abating GHG emissions and soil erosion were

442 evaluated by comparing marginal rates of substitution between feedstock cost and GHG

443 emissions and feedstock cost and soil erosion. The average imputed cost of abating GHG

444 emissions and soil erosion on the frontier was $\$ 2,378 \mathrm{Mg}^{-1}$ and $\$ 10 \mathrm{Mg}^{-1}$, respectively. This

445 finding suggests that soil erosion could be a more cost effective environmental criterion than

446 GHG emissions in the design of a sustainable switchgrass supply chain in Tennessee. However,

447 the compromise solution conversion facility site generated $63 \%$ higher feedstock cost compared

448 to the cost minimization location, but reduced soil erosion 70 fold and GHG emissions by $27 \%$.

449 The imputed costs of abating GHG emissions and soil erosion in the efficient set of supply chain

450 sites in Tennessee could provide policy makers important information for the development of a

451 sustainable switchgrass biofuels industry.

452 
453 Acknowledgements: This project was partially funded by USDA Agriculture and Food 454 Research Initiative Competitive Grant no. 2011-68005-30410; USDA National Institute of Food 455 and Agriculture, Sustainable Bioenergy Challenge Area grant award \#11025775; and US DOT 456 Grant no. DT0S5907G00050. The authors would also acknowledge Brad Wilson for data 457 preparation and management. The usual disclaimer applies. 


\section{References}

459 [1] U.S. Congress, Energy Independence and Security Act of 2007, (2007) Available at:

460 http://frwebgate.access.gpo.gov/cgi-

461 bin/getdoc.cgi?dbname=110_cong_bills\&docid=f:h6enr.txt.pdf.

462 [2] Larson JA, English BC, De La Torre Ugarte DG, Menard RJ, Hellwinckel CM, West TO,

463 Economic and environmental impacts of the corn grain ethanol industry on the United States

464 agricultural sector, Journal of Soil and Water Conservation, 65 (2010) 267-279.

465 [3] USDA Economic Research Service, Fuel ethanol, corn and gasoline prices, in: T. Capehart

466 (Ed.) U.S. Bioenergy Statistics, 2015.

467 [4] Searchinger T, Heimlich R, Houghton RA, Dong F, Elobeid A, Fabiosa J, Tokgoz S, Hayes

468 D, Yu TH, Use of U.S. croplands for biofuels increases greenhouse gases through emissions

469 from land-use change, Science, 319 (2008) 1238-1240.

470 [5] Hill J, Nelson E, Tilman D, Polasky S, Tiffany D, Environmental, economic, and energetic

471 costs and benefits of biodiesel and ethanol biofuels, Proceedings of the National Academy of

472 Sciences of the United States of America, 103 (2006) 11206-11210.

473 [6] Gelfand I, Zenone T, Jasrotia P, Chen J, Hamilton SK, Robertson GP, Carbon debt of

474 Conservation Reserve Program (CRP) grasslands converted to bioenergy production, Proc Natl

475 Acad Sci U S A, 108 (2011) 13864-13869.

476 [7] Tilman D, Socolow R, Foley JA, Hill J, Larson E, Lynd L, Pacala S, Reilly J, Searchinger T,

477 Somerville C, Williams R, Energy. Beneficial biofuels--the food, energy, and environment

478 trilemma, Science, 325 (2009) 270-271.

479 [8] Evers BJ, Blanco-Canqui H, Staggenborg SA, Tatarko J, Dedicated Bioenergy Crop Impacts

480 on Soil Wind Erodibility and Organic Carbon in Kansas, Agronomy Journal, 105 (2013) 1271.

481 [9] Vadas PA, Barnett KH, Undersander DJ, Economics and Energy of Ethanol Production from

482 Alfalfa, Corn, and Switchgrass in the Upper Midwest, USA, BioEnergy Research, 1 (2008) 44-

48355.

484 [10] Pimentel D, Harvey C, Resosudarmo P, Sinclair K, Kurz D, McNair M, Crist S, Shpritz L,

485 Fitton L, Saffouri R, Blair R, Environmental and economic costs of soil erosion and conservation

486 benefits, Science, 267 (1995) 1117-1123.

487 [11] U.S. EPA, Carbon Pollution Emission Guidelines for Existing Stationary Sources: Electric

488 Utility Generating Units, (2014) Available at:

489 http://yosemite.epa.gov/opei/rulegate.nsf/byRIN/2060-AR33.

490 [12] U.S. EPA, EPA Finalizes Regulations for the National Renewable Fuel Standard Program

491 for 2010 and Beyond, (2010) Available at:

492 http://www.epa.gov/otaq/renewablefuels/420f10007.pdf.

493 [13] Khanal S, Anex RP, Anderson CJ, Herzmann DE, Jha MK, Implications of biofuel policy-

494 driven land cover change for rainfall erosivity and soil erosion in the United States, Global

495 Change Biology Bioenergy, 5 (2013) 713-722. 
[14] Zhang G, Tang K, Ren Z, Zhang X, Impact of Grass Root Mass Density on Soil Detachment Capacity by Concentrated Flow on Steep Slopes, Transactions of the ASABE, (2013) 927-934. [15] McGranahan DA, Brown PW, Schulte LA, Tyndall JC, A historical primer on the US farm bill: Supply management and conservation policy, Journal of Soil and Water Conservation, 68 (2013) 67A-73A. [16] Lewandowski I, Scurlock JMO, Lindvall E, Christou M, The development and current status of perennial rhizomatous grasses as energy crops in the US and Europe, Biomass and Bioenergy, 25 (2003) 335-361. feedstock, Biofuels, Bioproducts and Biorefining, 2 (2008) 530-539. [18] Kort J, Collins M, Ditsch D, A review of soil erosion potential associated with biomass crops, Biomass and Bioenergy, 14 (1998) 351-359. [19] Monti A, Barbanti L, Zatta A, Zegada-Lizarazu W, The contribution of switchgrass in reducing GHG emissions, GCB Bioenergy, 4 (2012) 420-434. [20] Monti A, Fazio S, Venturi G, Cradle-to-farm gate life cycle assessment in perennial energy crops, European Journal of Agronomy, 31 (2009) 77-84. [21] Ziolkowska JR, Evaluating sustainability of biofuels feedstocks: A multi-objective framework for supporting decision making, Biomass and Bioenergy, 59 (2013) 425-440. [22] Khanna M, Dhungana B, Clifton-Brown J, Costs of producing miscanthus and switchgrass for bioenergy in Illinois, Biomass and Bioenergy, 32 (2008) 482-493. [23] Wesseler J, Opportunities ('costs) matter: A comment on Pimentel and Patzek "Ethanol production using corn, switchgrass, and wood; biodiesel production using soybean and sunflower", Energy Policy, 35 (2007) 1414-1416. [24] Pimentel D, Patzek TW, Ethanol Production Using Corn, Switchgrass, and Wood; Biodiesel Production Using Soybean and Sunflower, Natural Resources Research, 14 (2005) 65-76.

[25] Yu TE, He L, English BC, Larson JA, GIS-based optimization for advanced biofuels supply chains: a case study in Tennessee, Lecture Notes in Management Science, 6 (2014) 217-227. [26] Zhang J, Osmani A, Awudu I, Gonela V, An integrated optimization model for switchgrassbased bioethanol supply chain, Applied Energy, 102 (2013) 1205-1217. [27] Sokhansanj S, Kumar A, Turhollow A, Development and implementation of integrated biomass supply analysis and logistics model (IBSAL), Biomass and Bioenergy, 30 (2006) 838-

528 [28] Bernardi A, Giarola S, Bezzo F, Optimizing the economics and the carbon and water 529 footprints of bioethanol supply chains, Biofuel Bioprod Bior, 6 (2012) 656-672.

530 [29] Parish ES, Hilliard MR, Baskaran LM, Dale VH, Griffiths NA, Mulholland PJ, Sorokine A, 531 Thomas NA, Downing ME, Middleton RS, Multimetric spatial optimization of switchgrass 532 plantings across a watershed, Biofuel Bioprod Bior, 6 (2012) 58-72. 
533 [30] Nixon, J.D., P.K. Dey, P.A. Davies, S. Sagi, and R.F. Berry. Supply chain optimisation of

534 pyrolysis plant deployment using goal programming, Energy, 68 (2014) 262-271.

535 [31] You F, Tao L, Graziano DJ, Snyder SW, Optimal design of sustainable cellulosic biofuel

536 supply chains: Multiobjective optimization coupled with life cycle assessment and input-output 537 analysis, AIChE Journal, 58 (2012) 1157-1180.

538 [32] Yu TE, Wang Z, English BC, Larson JA, Designing a dedicated energy crop supply system 539 in Tennessee: a multiobjective optimization analysis, Journal of Agricultural and Applied 540 Economics, 46 (2014) 357-373.

541 [33] Chan Y, Economic Methods of Analysis, in: Location Theory and Decision Analysis, 542 Springer Berlin Heidelberg, 2011, pp. 17-82.

543 [34] Jäppinen E, Korpinen OJ, Ranta T, Effects of Local Biomass Availability and Road

544 Network Properties on the Greenhouse Gas Emissions of Biomass Supply Chain, ISRN

545 Renewable Energy, 2011 (2011) 1-6.

546 [35] Egbendewe-Mondzozo A, Swinton SM, Izaurralde CR, Manowitz DH, Zhang X, Biomass

547 supply from alternative cellulosic crops and crop residues: A spatially explicit bioeconomic

548 modeling approach, Biomass and Bioenergy, 35 (2011) 4636-4647.

549 [36] Jager HI, Baskaran LM, Brandt CC, Davis EB, Gunderson CA, Wullschleger SD, Empirical 550 geographic modeling of switchgrass yields in the United States, GCB Bioenergy, 2 (2010) 248551257.

552 [37] Wang M, Saricks C, Santini D, Effects of fuel ethanol use on fuel-cycle energy and 553 greenhouse gas emissions, (1999) Available at:

554 http://www.transportation.anl.gov/pdfs/TA/58.pdf.

555 [38] Tennessee Valley Authority Economic Development, Economic Development Sites and 556 Buildings, (2011) Available at:

557 http://www.tvasites.com/InSite.aspx?searchArea=FeaturedProperties.

558 [39] Reeves GR, Reid RC, Minimum values over the efficient set in multiple objective decision 559 making, European Journal of Operational Research, 36 (1988) 334-338.

560 [40] Mavrotas G, Florios K, An improved version of the augmented $\varepsilon$-constraint method 561 (AUGMECON2) for finding the exact pareto set in multi-objective integer programming 562 problems, Applied Mathematics and Computation, 219 (2013) 9652-9669.

563 [41] Ramos TRP, Gomes MI, Barbosa-Póvoa AP, Planning a sustainable reverse logistics 564 system: Balancing costs with environmental and social concerns, Omega, 48 (2014) 60-74.

565 [42] Larson JA, Yu TE, English BC, Jensen KL, Gao Y, Wang C, Effect of outdoor storage 566 losses on feedstock inventory management and plant-gate cost for a switchgrass conversion 567 facility in East Tennessee, Renewable Energy, 74 (2015) 803-814.

568 [43] Duffy M, Estimated Costs for Production, Storage and Transportation of Switchgrass, 569 (2007) Available at: http://www2.econ.iastate.edu/research/webpapers/paper_12917.pdf. 
[44] Wischmeier WH, Smith DD, Predicting rainfall erosion losses--a guide to conservation planning, Supersedes Agriculture Handbook No. 282, (1978) Available at: http://www.ars.usda.gov/SP2UserFiles/ad_hoc/36021500USLEDatabase/AH_537.pdf. [45] Renard KG, Foster GR, Weesies GA, McCool DK, Yoder DC, Predicting soil erosion by water: a guide to conservation planning with the revised unversal soil loss equation, (1997) Available at: http://www.ars.usda.gov/SP2UserFiles/Place/64080530/RUSLE/AH_703.pdf. [46] Kokkinidis I, Ecosystem Services Provided by Agricultural Land as Modeled by Broad Scale Geospatial Analysis, in, Virginia Polytechnic Institute and State University, 2014. [47] United States Department of Agriculture, Web Soil Survey, (2013) Available at: http://websoilsurvey.nrcs.usda.gov/.

580 [48] U.S. Department of Agriculture Natural Resources Conservation Service, National Soil 581 Survey Handbook, (2014) Available at:

582 http://www.nrcs.usda.gov/wps/portal/nrcs/detail/soils/survey/?cid=nrcs142p2_054242.

583 [49] Olson DL, Tchebycheff norms in multi-objective linear programming, Mathematical and 584 Computer Modelling, 17 (1993) 113-124.

585 [50] Clemen RT, Reilly T, Making hard decisions with DecisionTools Suite, (1999).

586 [51] Schimel DS, Carbon and nitrogen turnover in adjacent grassland and cropland ecosystems, 587 Biogeochemistry, 2 (1986) 345-357.

588 [52] Aalde H, Gonzalez P, Gytarsky M, Krug T, Kurz WA, Lasco RD, Martino DL, G. B, 589 McConkey, Ogle S, Paustian K, Raison J, Ravindranath NH, Schoene D, Smith P, Somogyi Z, 590 van A, Amstel, Verchot L, Generic methodologies applicable to multiple landuse categories, in:

591 S. Eggleston, L. Buendia, K. Miwa, T. Ngara, K. Tanabe (Eds.) IPCC Guidelines for National 592 Greenhouse Gas Inventories, IGES, Japan, 2006.

593 [53] Argone National Laboratory, The Greenhouse Gases, Regulated Emissions, and Energy Use 594 in Transportation Model (GREET), (2013) Available at:

595 http://www.transportation.anl.gov/publications/index.html.

596 [54] U.S. EPA, Motor Vehicle Emission Simulator (MOVES) model, (2013).

597 [55] Cherubini F, Jungmeier G, LCA of a biorefinery concept producing bioethanol, bioenergy, 598 and chemicals from switchgrass, The International Journal of Life Cycle Assessment, 15 (2009) 599 53-66.

600 [56] U.S. Department of Agriculture Nature Resources Conservation Service, Soil Survey 601 Geographical Database (SSURGO), (2012) Available at:

602 http://soils.usda.gov/survey/geography/ssurgo/.

603 [57] U.S. Department of Agriculture NASS, CropScape - Cropland Data Layer Database, (2011) 604 Available at: http://nassgeodata.gmu.edu/CropScape.

605 [58] U.S. Department of Agriculture NASS, Crop Values Annual Summary, (2014) Available 606 at: http://usda.mannlib.cornell.edu/MannUsda/viewDocumentInfo.do?documentID=1050 
607 [59] De La Torre Ugarte DG, Ray DE, Biomass and bioenergy applications of the POLYSYS

608 modeling framework Paper prepared for presentation at the Modeling Tools for Biomass and

609 Bioenergy Conference, 8-10 April 1997 Knoxville, TN, Biomass and Bioenergy, 18 (2000) 291-

610308.

611 [60] Larson JA, Yu TE, English BC, Mooney DF, Wang C, Cost evaluation of alternative

612 switchgrass producing, harvesting, storing, and transporting systems and their logistics in the

613 Southeastern USA, Agricultural Finance Review, 70 (2010) 184-200.

614 [61] University of Tennessee, Field crop budgets, (2015) Available at:

615 http://economics.ag.utk.edu/budgets.html.

616 [62] Schimel DS, Ojima DS, Hartman MD, Parton WJ, Brenner J, Mosier AR, Grosso SJD,

617 Simulated Interaction of Carbon Dynamics and Nitrogen Trace Gas Fluxes Using the

618 DAYCENT Model, in: S. Hansen, M.J. Shaffer, L. Ma (Eds.) Modeling Carbon and Nitrogen

619 Dynamics for Soil Management, CRC Press, 2001.

620 [63] Fribourg HA, Loveland RW, Seasonal Production, Perloline Content, and Quality of Fescue

621 After N Fertilization1, Agronomy Journal, 70 (1978) 741.

622 [64] Bowling RG, McKinley TL, Rawls EL, Tennessee Forage Budgets, UT extension, (2006)

62323 Available at: http://economics.ag.utk.edu/budgets/PB1658ForageBudgets07.pdf.

624 [65] Muir JP, Sanderson MA, Ocumpaugh WR, Jones RM, Reed RL, Biomass Production of

625 'Alamo' Switchgrass in Response to Nitrogen, Phosphorus, and Row Spacing, Agronomy

626 Journal, 93 (2001) 896.

627 [66] Mitasova H, Hofierka J, Zlocha M, Iverson LR, Modelling topographic potential for erosion

628 and deposition using GIS, International Journal of Geographical Information Systems, 10 (1996)

629 629-641.

630 [67] Mitasova H, Brown WM, Hohmann M, Warren S, Using Soil Erosion Modeling for

631 Improved Conservation Planning: A GIS-based Tutorial, (2001) Available at:

632 http://www4.ncsu.edu/ hmitaso/gmslab/reports/CerlErosionTutorial/denix/denixstart.html.

633 [68] American Agricultural Economics Association, Commodity Cost and Returns Handbook,

634 in, Ames, IA, 2000.

635 [69] American Society of Agricultural and Biological Engineers, Agricultural Machinery

636 Standards, in, St. Joseph, MI, 2006.

637 
Table 1 Definitions of Subscripts, Parameters and Variables

\begin{tabular}{|c|c|c|}
\hline & Unit & Definition \\
\hline \multicolumn{3}{|l|}{ Subscripts } \\
\hline$i$ & & Land resource units \\
\hline$j$ & & Industrial park sites for conversion facility \\
\hline$m$ & & Month \\
\hline$p$ & & $\begin{array}{l}\text { Type of crop land (hay and pasture, corn, soybean, wheat, } \\
\text { sorghum, cotton) }\end{array}$ \\
\hline$k$ & & Type of machinery (tractor, mower, loader, rake, baler) \\
\hline \multicolumn{3}{|l|}{ Parameters } \\
\hline Price & $\$ \mathrm{Mg}^{-1}$ & Crop prices \\
\hline Yield & $\mathrm{Mg} \mathrm{ha}^{-1}$ & Crop yields \\
\hline$P C$ & $\$ \mathrm{ha}^{-1}$ & Crop production costs \\
\hline Yield & $\mathrm{Mg} \mathrm{ha}^{-1}$ & Switchgrass yields \\
\hline$L R$ & $\$ \mathrm{Mg} \mathrm{ha}^{-1}$ & Land rent \\
\hline Est & $\$ \mathrm{ha}^{-1}$ & Switchgrass establishment cost \\
\hline$A M$ & $\$$ ha $^{-1}$ & Annual maintenance cost \\
\hline$\sigma$ & $\$ \mathrm{ha}^{-1}$ & Cost of harvesting switchgrass \\
\hline$\gamma$ & $\$ \mathrm{ha}^{-1}$ & Cost per unit of storing switchgrass \\
\hline$\theta$ & $\$ \mathrm{ha}^{-1}$ & Cost per unit of transporting switchgrass \\
\hline$D M L$ & $\%$ & Dry matter loss during transportation \\
\hline$A a$ & ha & Crop land available in each land resource unit \\
\hline Avehour & Hour & Average working hours of machinery in each month \\
\hline$D M L$ & $\%$ & Dry matter loss during storage \\
\hline MTB & hours ha ${ }^{-1}$ & Machine time $\mathrm{ha}^{-1}$ for each machinery \\
\hline$\Lambda$ & $\mathrm{L} \mathrm{Mg}^{-1}$ & Switchgrass-ethanol conversional rate \\
\hline$Q$ & $\mathrm{~L}_{\text {month }}{ }^{-1}$ & Monthly demand for ethanol \\
\hline$\triangle \mathrm{LUCO} \mathrm{O}_{2}$ & $\mathrm{CO}_{2} \mathrm{e} \mathrm{kg} \mathrm{ha}{ }^{-1}$ & $\mathrm{CO}_{2}$ emission from land conversion \\
\hline$\triangle \mathrm{LUCH}_{4}$ & $\mathrm{CO}_{2} \mathrm{e} \mathrm{kg} \mathrm{ha}^{-1}$ & $\mathrm{CH}_{4}$ emission from land conversion \\
\hline$\triangle L U N_{2} \mathrm{O}$ & $\mathrm{CO}_{2} \mathrm{e} \mathrm{kg} \mathrm{ha}{ }^{-1}$ & $\mathrm{~N}_{2} \mathrm{O}$ emission from land conversion \\
\hline ProE & $\mathrm{CO}_{2} \mathrm{e} \mathrm{kg} \mathrm{ha}^{-1}$ & $\begin{array}{l}\text { GHG emissions factor from energy use during Switchgrass } \\
\text { production }\end{array}$ \\
\hline HarE & $\mathrm{CO}_{2} \mathrm{e} \mathrm{kg} \mathrm{ha}^{-1}$ & GHG emissions factor from energy usage during harvest \\
\hline StorE & $\mathrm{CO}_{2} \mathrm{e} \mathrm{kg} \mathrm{ha}{ }^{-1}$ & GHG emissions factor from energy usage during storage \\
\hline MachE & $\mathrm{CO}_{2} \mathrm{e} \mathrm{kg} \mathrm{\text {unit } ^ { - 1 }}$ & GHG emissions factor from machinery production \\
\hline TransE & $\mathrm{CO}_{2} \mathrm{e} \mathrm{kg}$ route $^{-1}$ & GHG emissions from energy usage during transportation \\
\hline Loadwt & $\mathrm{Mg}$ truck $^{-1}$ & Switchgrass delivered per truck \\
\hline FertE & $\mathrm{CO}_{2} \mathrm{e} \mathrm{kg} \mathrm{Mg}$ & GHG emissions factor from fertilizer production \\
\hline ChemE & $\mathrm{CO}_{2} \mathrm{e} \mathrm{kg} \mathrm{Mg}^{-1}$ & GHG emissions factor from chemical production \\
\hline SeedE & $\mathrm{CO}_{2} \mathrm{e} \mathrm{kg} \mathrm{Mg}^{-1}$ & GHG emissions factor from seed production \\
\hline$U$ & & Upper bound values for certain objective \\
\hline$L$ & & Lower bound values for certain objective \\
\hline$R$ & & Range of certain objective \\
\hline \multicolumn{3}{|l|}{ Variables } \\
\hline $\mathrm{AH}$ & ha & Area of switchgrass harvested \\
\hline XTN & $\mathrm{Mg}$ & Switchgrass transported directly to the biorefinery \\
\hline NXE & $\mathrm{Mg}$ & Switchgrass stored during harvest season \\
\hline XE & $\mathrm{Mg}$ & Cumulative switchgrass storage \\
\hline XTO & $\mathrm{Mg}$ & Switchgrass transported from storage to the biorefinery \\
\hline NM & Unit & Number of equipment used for harvest \\
\hline
\end{tabular}


Table 2 Data sources

\begin{tabular}{|c|c|c|c|}
\hline & Economic Cost & GHG Emissions & Soil Erosion \\
\hline $\begin{array}{l}\text { Land } \\
\text { conversion from } \\
\text { crop land to } \\
\text { switchgrass }\end{array}$ & $\begin{array}{l}\text { Opportunity cost: } \\
\text { Crop yields: USDA SSURGO [56]; } \\
\text { Crop price and hectares: USDA NASS [57, 58]; } \\
\text { Crop production cost: USDA ERS [58], } \\
\text { POLYSIS [59] } \\
\text { Switchgrass plantation: } \\
\text { Yield: Jager et al. [36]; } \\
\text { Production and harvest Cost: Larson, et al. [60], } \\
\text { University of Tennessee [61] }\end{array}$ & $\begin{array}{l}\text { Land use change (Daycent [62]): } \\
\text { Weather data: DayMET }{ }^{1} ; \\
\text { Soil texture: USDA SSURGO }{ }^{3} \text { [56] } \\
\text { Management practice for crops: } \\
\text { University of Tennessee [61] } \\
\text { Hay/pasture management: [63, 64] } \\
\text { Switchgrass management: }[65]\end{array}$ & $\begin{array}{l}\text { R factor: USDA RUSLE2 }{ }^{2} \\
\text { K factor: USDA SSURGO } \\
\text { [56] } \\
\text { C factor: USDA RUSLE2, } \\
\text { [64,65] } \\
\text { P factor: [64] } \\
\text { LS factor: Drained area } \\
\text { method [66, 67]. }\end{array}$ \\
\hline Production & $\begin{array}{l}\text { Establishment: American Agricultural Economics } \\
\text { Association [68] } \\
\text { Annual maintenance: American Society of } \\
\text { Agricultural and Biological Engineers [69] }\end{array}$ & $\begin{array}{l}\text { Fuel usage: GREET [53] } \\
\text { Fertilizer, herbicide, seed: GREET [53] } \\
\text { Machine production: GREET [53] }\end{array}$ & \\
\hline Harvest & Fuels and labors: University of Tennessee [61] & $\begin{array}{l}\text { Fuel: GREET [53] } \\
\text { Machine production: GREET [53] }\end{array}$ & \\
\hline Storage & Covers and pallets: University of Tennessee [61] & & \\
\hline Transportation & $\begin{array}{l}\text { Trailer, fuel and labor: University of Tennessee } \\
\text { [61] }\end{array}$ & $\begin{array}{l}\text { MOVES modeling [54]; } \\
\text { Indirect emission from truck } \\
\text { production: GREET [53] }\end{array}$ & \\
\hline
\end{tabular}

1 http://daymet.ornl.gov/

2 RUSLE2 model website: http://fargo.nserl.purdue.edu/rusle2_dataweb/RUSLE2_Index.htm

3 SSURGO database: http://www.nrcs.usda.gov/wps/portal/nrcs/detail/soils/survey/geo/?cid=nrcs142p2_053627 
Table 3 Output summary for the single objective solutions and the compromise solution

\section{Feedstock cost minimization}

(A)

GHG
emissions
minimization

(B)

Soil
erosion

(C)
Compromise solution
Cost item

Opportunity cost

Production cost

Harvest cost

Storage cost

Transportation cost

Total cost

Total GHG emissions

\subsection{4}

8.606

22.395

2.775

8.307

43.417

44.887

$$
\text { \$ (millions) }
$$

15.697

35.628

22.056

8.773

8.572

8.617

22.409

2.775

2.775

2.775

14.881

10.607

16.081

70.738

$\mathrm{Mg}$ (thousand)

$\begin{array}{lll}18.587 & 29.689 & 32.844\end{array}$

$\mathrm{Mg}$ (million)

Total soil erosion

$-0.106$

$-3.545$

$-7.646$

$-7.495$ 
Harvest season transportation

\begin{tabular}{|c|c|c|c|c|c|}
\hline & \multicolumn{3}{|c|}{$=0$} & \\
\hline & & & & & \\
\hline $\begin{array}{l}\text { Land resources } \\
\text { unit }\end{array}$ & $\begin{array}{l}\text { Switchgrass } \\
\text { production } \\
\text { (AH) }\end{array}$ & $\begin{array}{l}\text { Newly Stored } \\
\text { Feedstock } \rightarrow \\
(\text { NXS })\end{array}$ & Storage (XS) & $\begin{array}{c}\text { Utt-harvest } \\
\text { season } \\
\text { transportation }\end{array}$ & $\begin{array}{l}\text { Conversion } \\
\text { facility }\end{array}$ \\
\hline
\end{tabular}

Figure 1 System boundary of switchgrass supply chain: field to conversion facility 


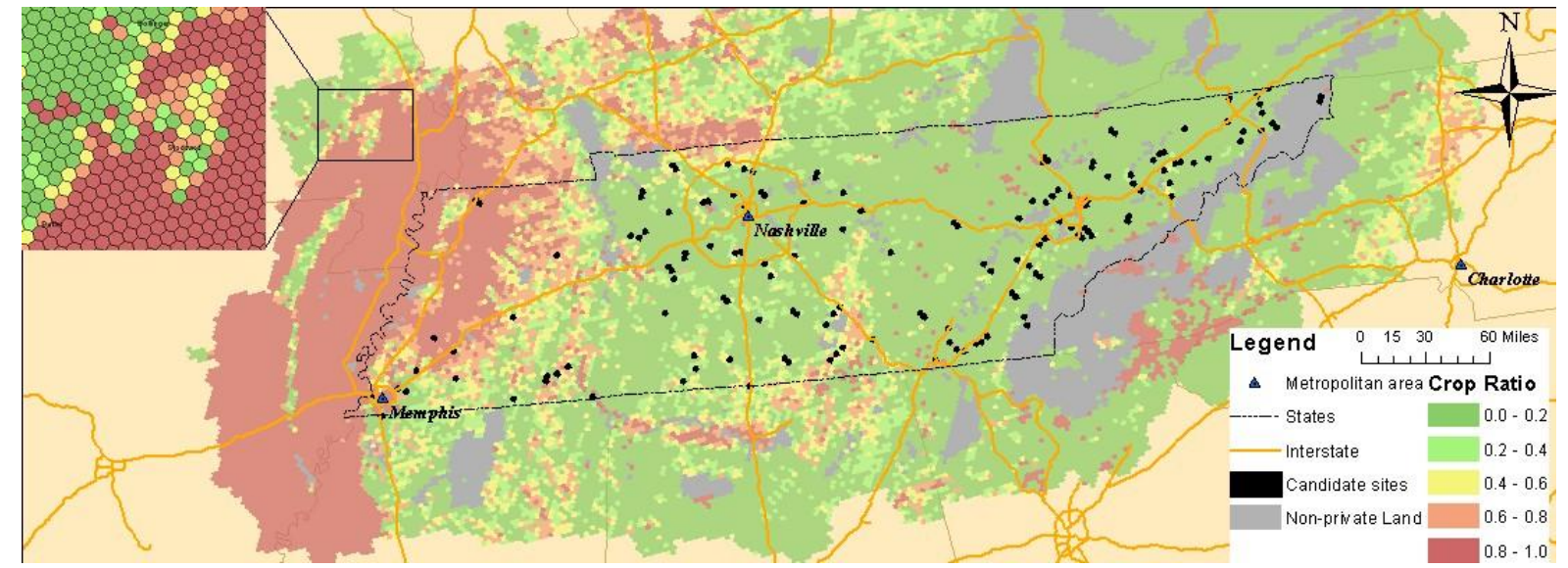

Figure 2 Potential switchgrass supply area and industrial park sites for conversion facilities

Note: Crop ratio is the ratio of crop land to hay and pasture lands. 
3-i: Solution projection on each coordinator panel for one conversion facility site

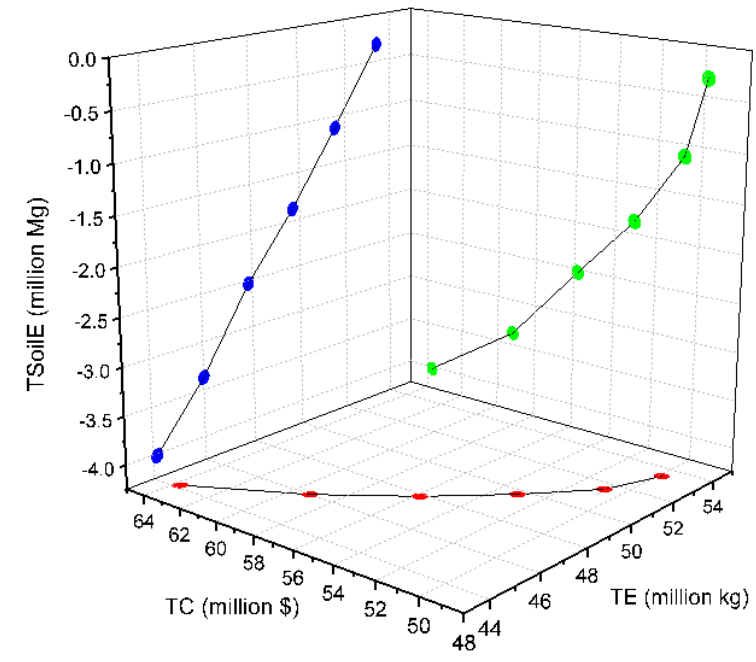

3-ii: Solution projection on each coordinator panel

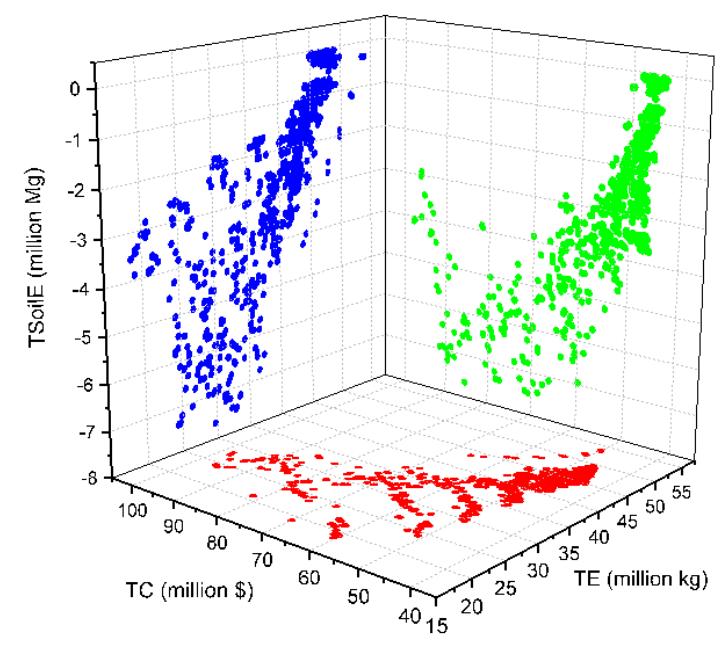

3-iii: efficient frontier embracing feasible points

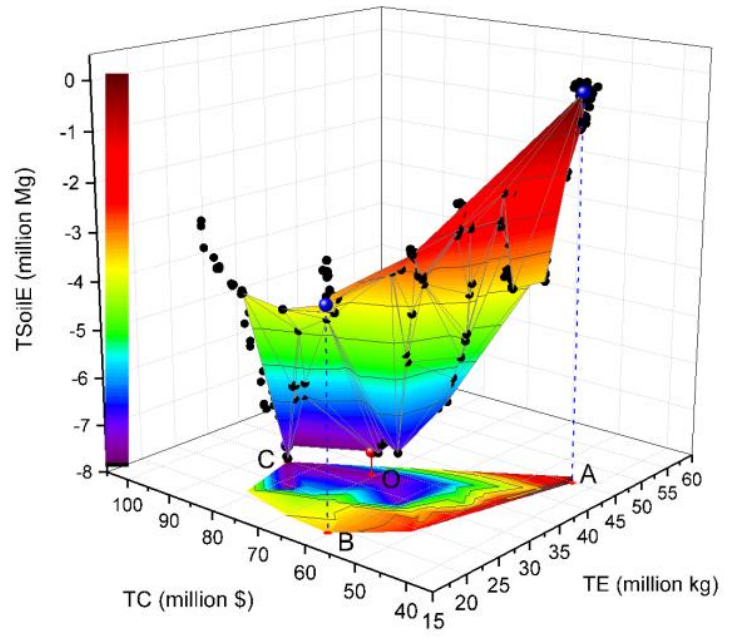

Figure 3 Regional feasible solutions (A: total cost minimization, B:GHG emission minimization, $\mathrm{C}$ : soil erosion minimization, $\mathrm{O}$ : compromise solution) 
4-i: Total feedstock cost minimization (A)

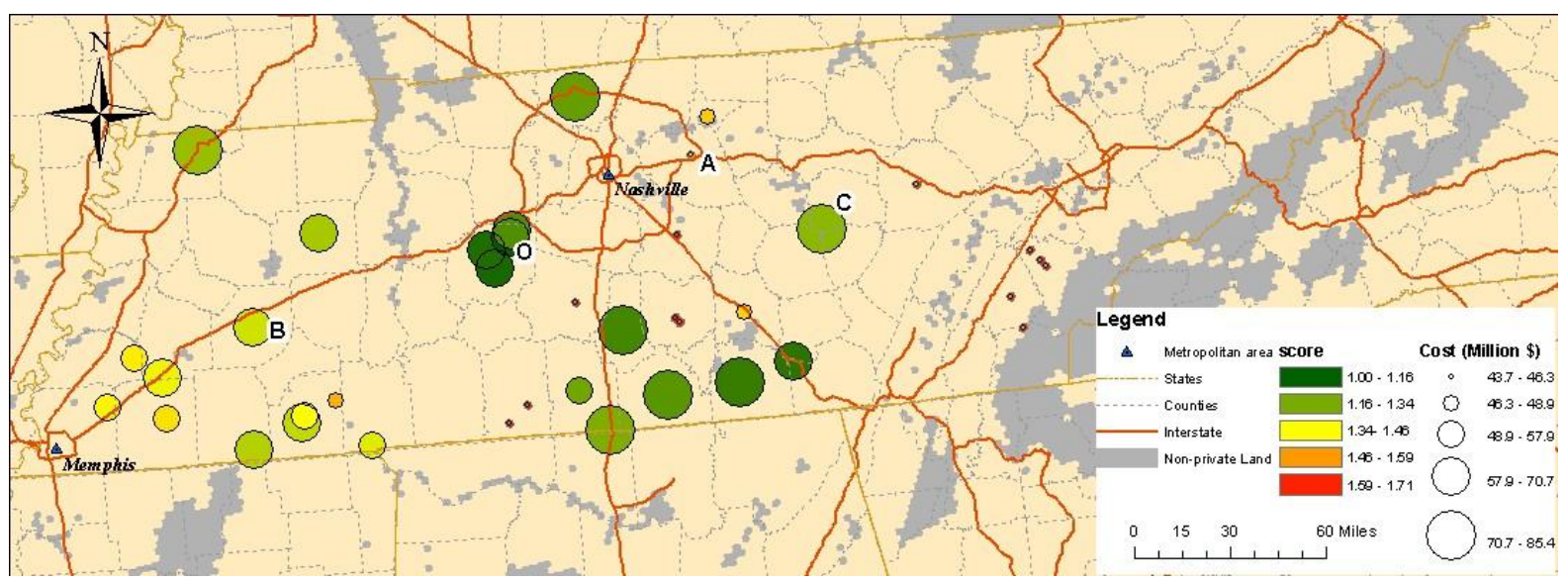

4-ii: GHG emission minimization (B)

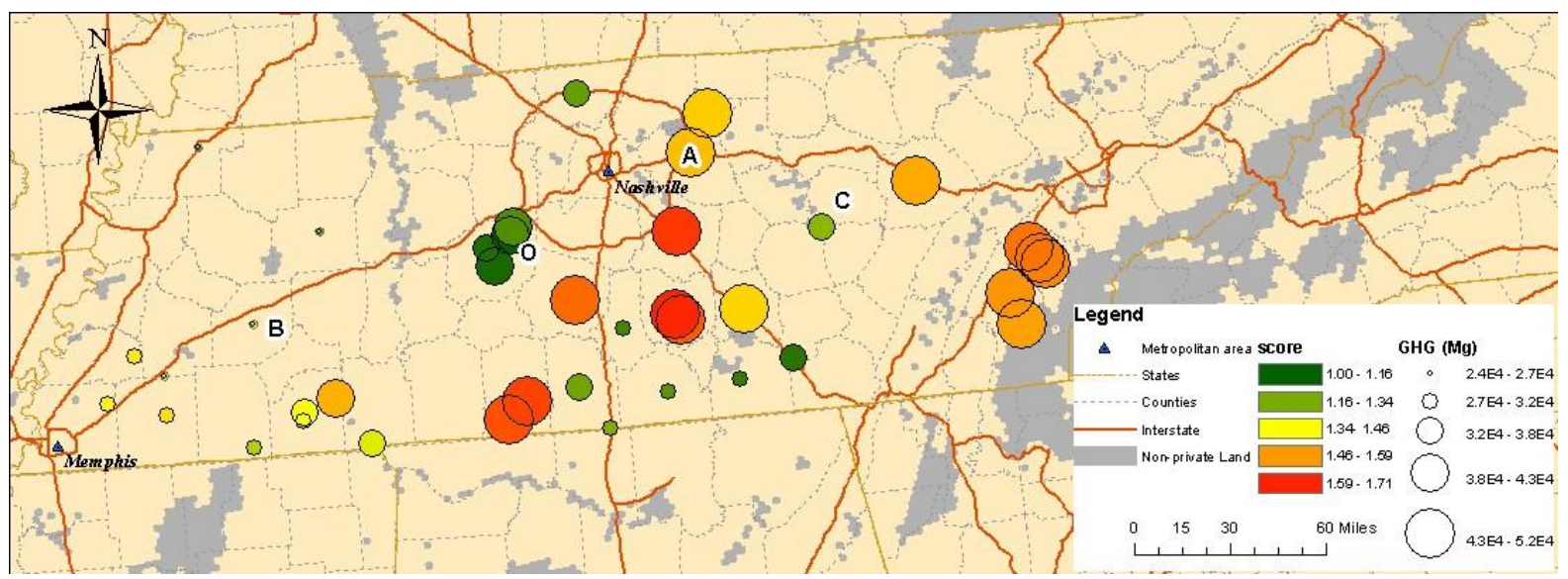

4-iii: Soil erosion minimization (C)

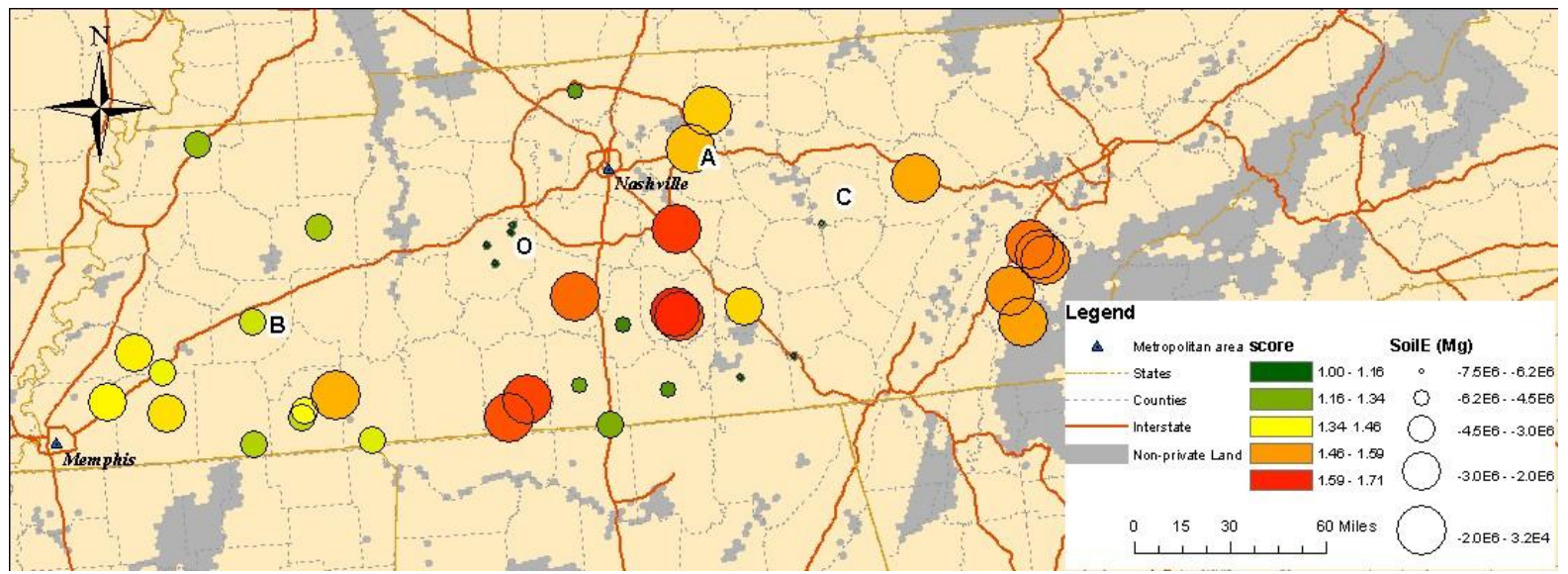

Figure 4 Distance scores and objective values for the 40 conversion facility sites on the efficient frontier. 
5-i: Individual optima for total cost minimization (A)

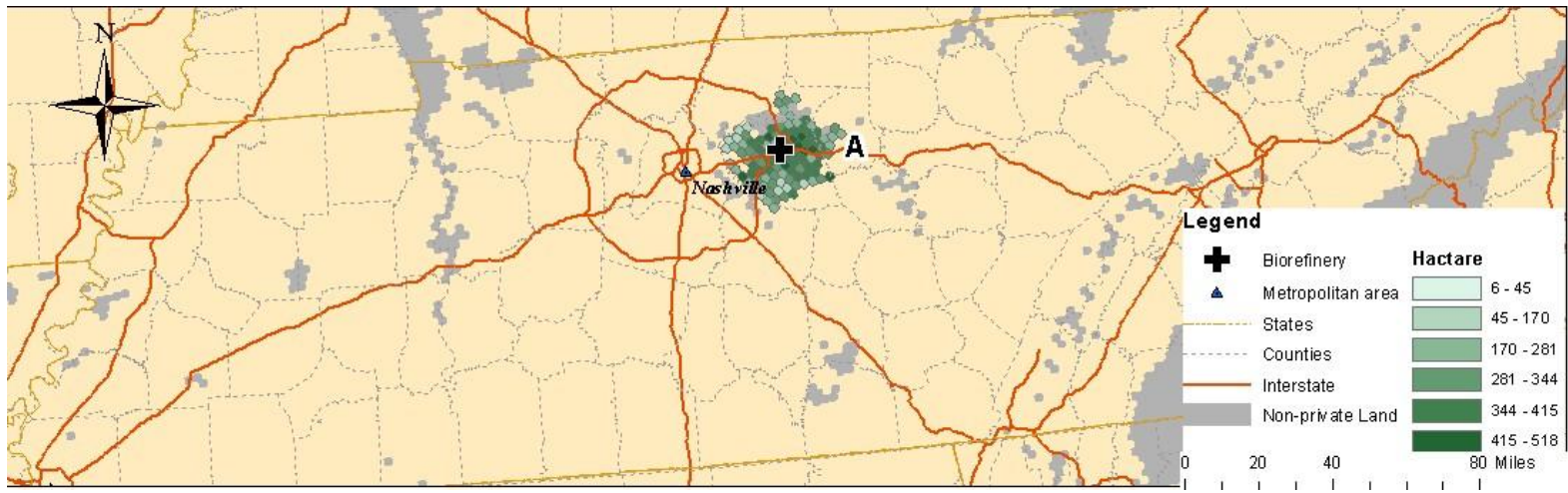

5-ii: Individual optima for GHG emission minimization (B)

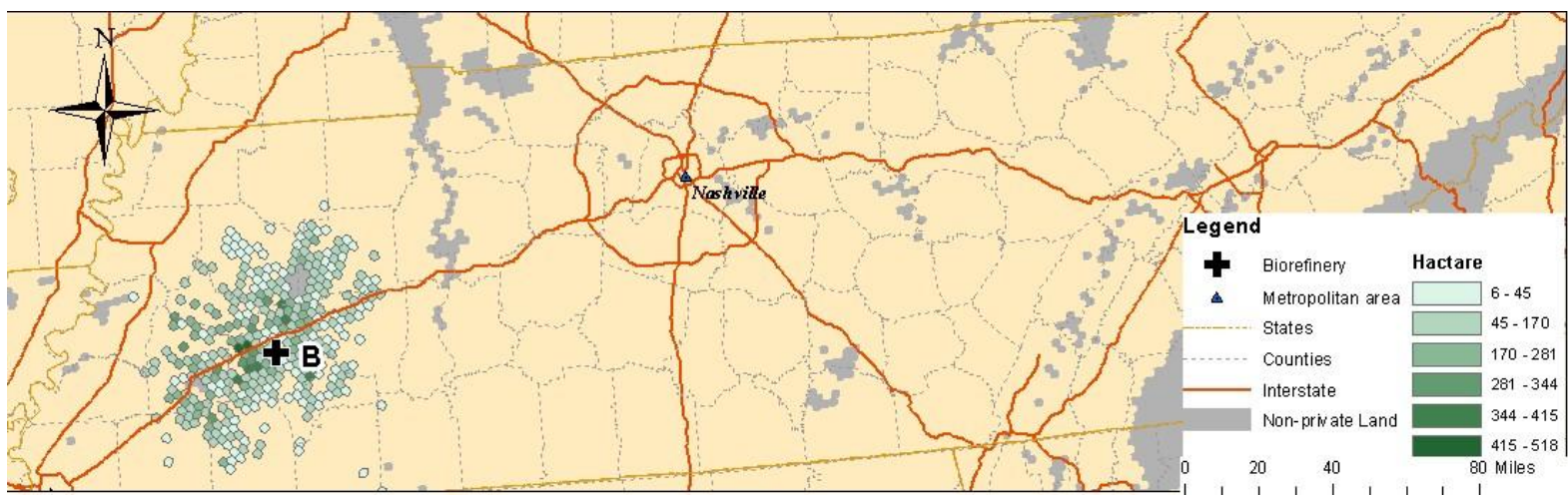

5-iii: Individual optima for soil erosion minimization (C)

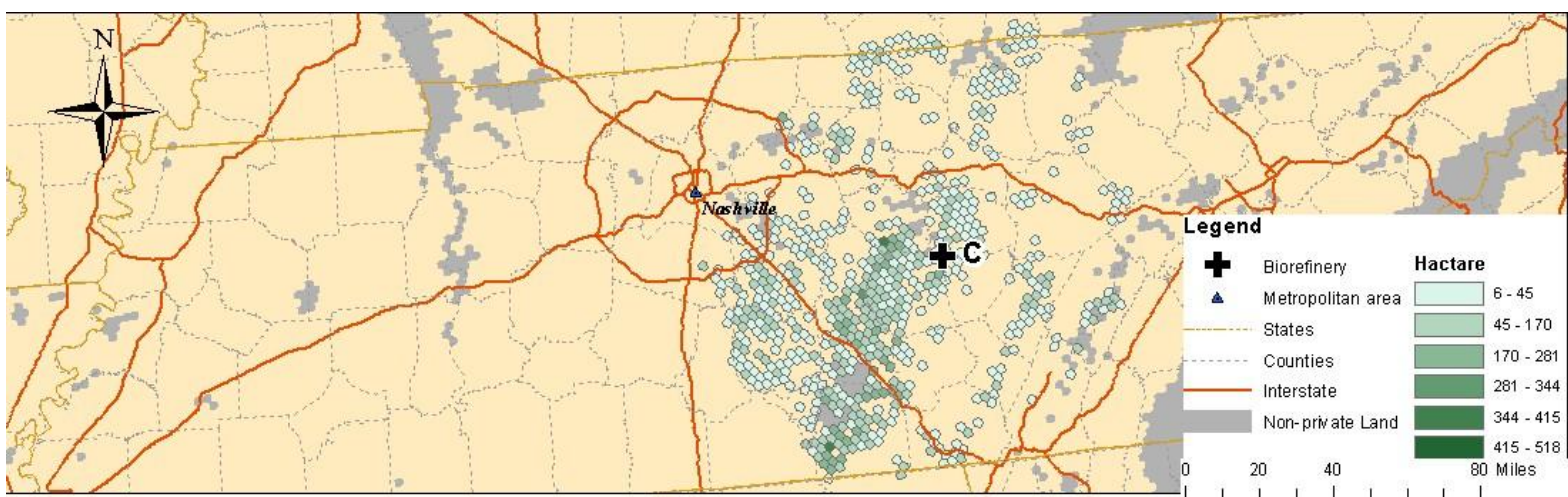

5-iv: Compromise solution $(\mathrm{O})$

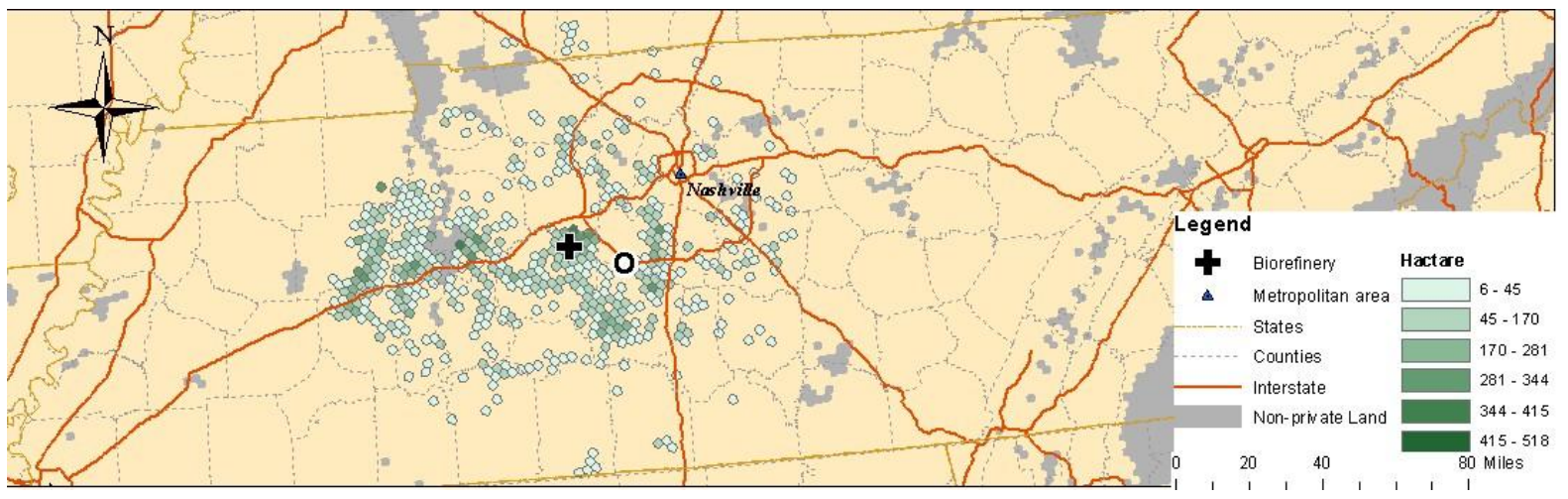

Figure 5 Placement of the conversion facility and switchgrass draw area under individual-optima and compromise solution cases 
$\square$ Corn $\square$ Cotton $\square$ Hay \& Pasture $\square$ Sorghum $\square$ Soybeans $\square$ Wheat

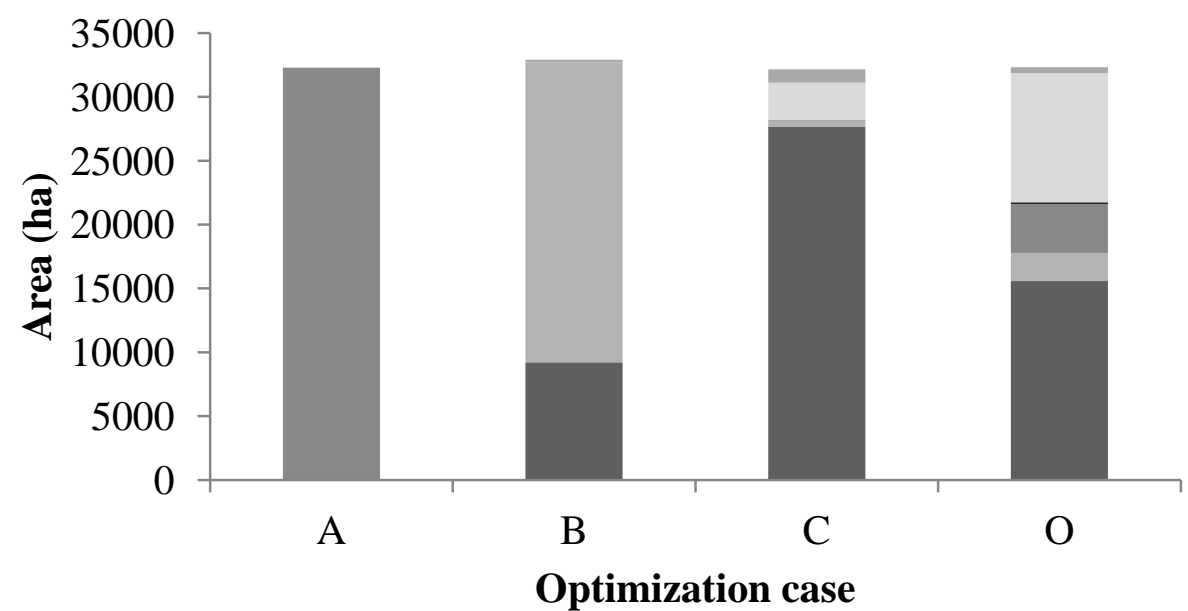

Figure 6 Land area converted to switchgrass for each optimization case (A: total cost minimization, B: GHG emission minimization, C: soil erosion minimization, $O$ : compromise solution) 


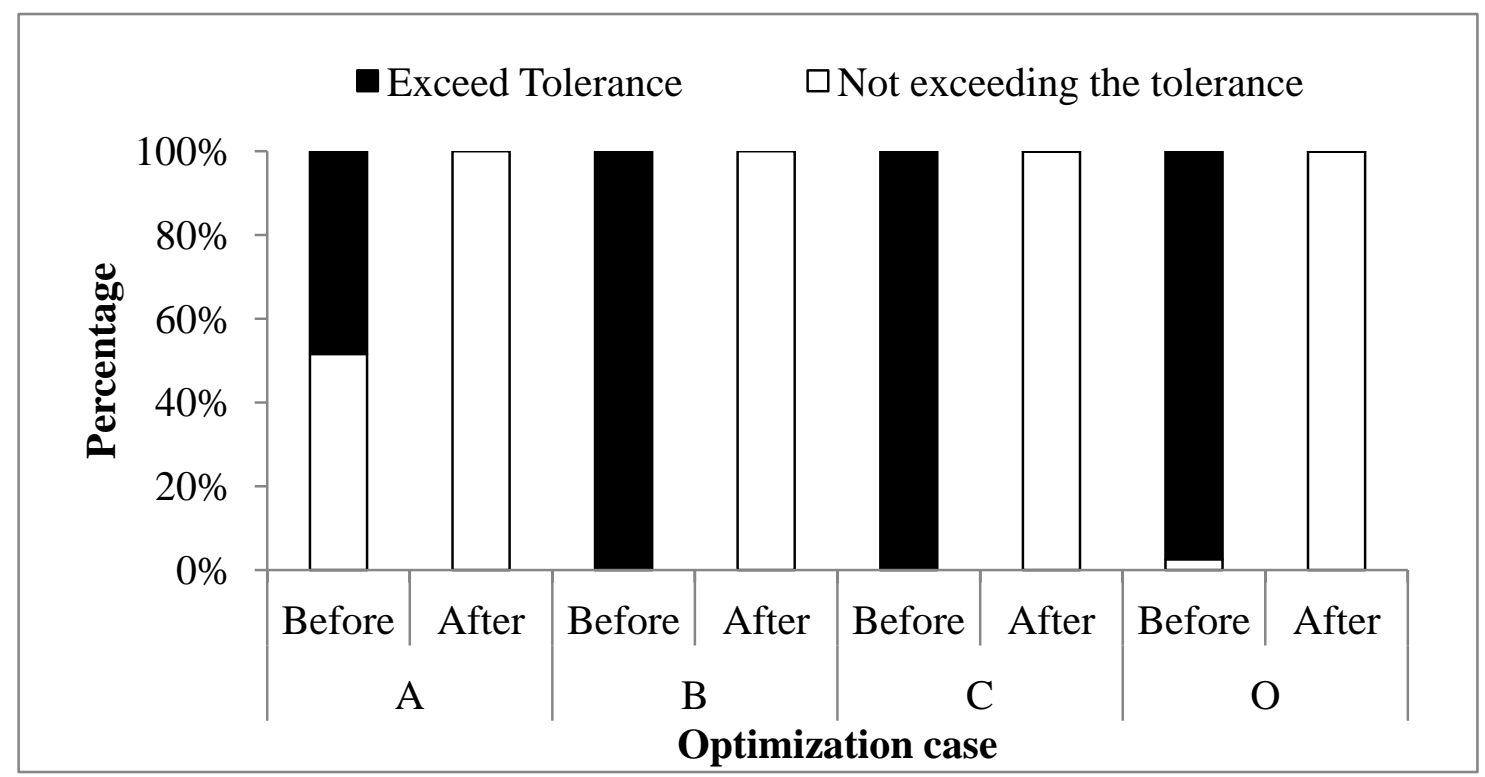

Figure 7 Changes in soil erosion within the feedstock draw area before and after the land was converted to switchgrass (A: total cost minimization, B: GHG emission minimization, $\mathrm{C}$ : soil erosion minimization, $\mathrm{O}$ : compromise solution) 